the level appropriate to their qualifications and value to the Laboratory, would be, in the opinion of the Committee, of great benefit to the Laboratory.

The eighth in the series of international symposia, dealing with visual problems of colour, was held at the Laboratory during September 23-25. The proceedings of the symposium on the direction of research establishments which was held in September 1956 ; two booklets, Nos. 16 and 18, in the series "Notes on Applied Science" ; and the first volume, "The Use and Construction of Mathematical Tables", in the new series entitled "NPL Mathematical Tables", were published during the year. In addition to visits to the Laboratory by numerous scientists from many countries, including two Russian parties interested in thermodynamics and the properties of steel and a group of Chinese scientists forming part of a trade delegation, the Parliamentary and scientific Committee visited the Laboratory to see some of its work and to discuss its organization.

The Laboratory provided a number of items for inclusion in the stands of the Department of Scientific and Industrial Research at the Physical Society Exhibition of scientific apparatus, the Plastics Exhibition and the Engineering, Marine, Welding and Nuclear Energy Exhibition, and displays were shown at the Royal Society soirées and at the Geological Society of London. Seventy-two visits overseas were made by members of the staff, consisting of nine to the United States and Canada, three to Australia and the remainder to Europe.
A long-standing need at the Laboratory is a centre incorporating a first-class lecture hall, restaurant facilities and library, and it is therefore pleasant to read in the report that planning has begun for the conversion of the duplex wind tunnel building into such a centre. The first phase of the conversion will provide a lecture hall, restaurant and cafeteria, conference rooms and an exhibition hall, and the second phase possibly the rehousing of the library. The building work in connexion with the new Ship Hydrodynamics Laboratory at Feltham is proceeding satisfactorily, and that Laboratory should be in full operation by late 1959. A new workshop and a drawing office have been provided for the Aerodynamies Division, and an extension has been made to the control mechanisms building of the Control Mechanisms and Electronics Division.

The recent and more interesting activities of the various sections of the Laboratory are always illus. trated and displayed during the open days, and the detailed descriptions of these given in the reports already published in Nature $(180,166 ; 1957$; and 182,$10 ; 1958$ ) make superfluous any additional reference to the substance of the superintendents' reports contained in the annual report. The reports, however, are well worth close study, as they indicate most clearly the very wide range of extremely careful and accurate investigations, relating to both fundamental and applied research, undertaken by the Laboratory. A bibliographical list of publications by members of the staff of the appropriate division accompanies each report.

S. WEINTROUB

\title{
FIRE RESEARCH
}

$\mathrm{F}^{\mathrm{on}}$ OR some years now, Britain has occupied a leading position in the conduct of research into fire and explosion. This is no less than is to be expected, for not only are these matters of domestic concern, but also, by reason of the world-wide nature of British insurance, there is little that happens elsewhere that is of no material interest to us.

An important stage was reached in the 1930 's when the Riverdale Committee, reviewing fire brigade services in England and Wales, recommended the establishment of a Fire Prevention Research Board by the Department of Scientific and Industrial Research. Only the first practical steps had been taken when the Second World War began.

War-time experience soon showed that in air raids, damage due to fire can greatly exceed in extent that due to high-explosive bombs. For this reason, wartime fire research was developed and conducted under the rgis of the Ministry of Home Security, and a considerable number of internal and extramural projects were organized and brought to successful issue. After the War, the Department of scientific and Industrial Research again assumed responsibility for fire research, and in November 1946 established, now in partnership with the Fire Offices' Committee, representing the insurance companies, the Fire Research Board and the Joint Fire Researeh Organization. The Fire Offices' Committee placed at the disposal of the organization its Fire Testing Station at Boreham Wood, which had been established in 1935, and this became the site of the new research station. Additional facilities, some of a temporary nature, have been acquired, and final plans for permanent buildings are now far advanced. One further development should be mentioned. In 1955 the Fire Research Board set up a Committee on Industrial Fires and Explosions to advise with regard to research upon problems encountered by the Factory Inspectorate and others in contact with industry. This step was associated with a very desirable broadening of the interests of the organization into the field of industrial hazards.

An impression of the growth of the work as a whole is gained by comparing the first report of the Board and the Director, issued in 1947, with that for $1957^{*}$, which has recently appeared. In the intervening ten years, both the scope of the work and the staff employed have greatly increased, but it is gratifying to note that the length of the report has not increased proportionately.

The statistics with regard to fires attended by fire brigades in the United Kingdom during 1956 and the preceding years are of popular interest, and provide a background against which much of the other work must be viewed. For this reason it is a little surprising that the figures do not receive more comment in the report itself. They reveal a marked recent increase in the total number of fires; to which increase, fires in the open (grassland, heathland, woodland, embankments, lefuse, etc.) have contributed most notably. So far as fires in buildings are concerned,

* Department of Scientiflc and Industrial Research and Fire Offices' Committe. Fire Research 1957: Report of Fire Research Board and the Report of the Director of Fire Research. Pp. vi $+52+8$ plates. (Tondon: H.M. Stationery Office 1958.) 5 s. net. 
the increase is fairly evenly spread over the different types. The most marked, however, is seen in the "other buildings" category, and, as these account for some 10 per cent of the total building fires, further analysis seems to be desirable. A similar remark applies to the analysis of electrical causes of fire where, although most of the defined categories show that the situation is at least under control, "other apparatus" is responsible for growing numbers of fires. The use of oil-burning appliances in buildings is an increasingly important cause, and attention is directed to this matter in the report, where it is pointed out that a disturbing number of fatalities is associated with fires of this type.

In a review of this character it is impossible to do justice to the considerable amount of excellent experimental work that is recorded. Mention may be made of the continuation of the fruitful investigation of the ignition of solid materials by radiated heat, and the interesting experiments on the correlation of fires in buildings with those in models. Among building materials, ordinary and pre-stressed concrete have received particular attention as to their behaviour in fire; while on the operational side, attempts are being made to put the application of fire detectors and the use of water sprays and foam as extinguishing media on a scientific footing. Work on industrial explosions has been directed particularly to the scope and limitations of explosion reliefs and flame arrestors; and a study has been made of the significance of the readings of commercial explosimeters when applied to vapours of diverse nature. Work on the flammability of fabrics is being directed to the important question of the personal hazard arising from the ignition of clothing and to the development of a relevant test. Several smaller but no less interesting investigations complete the list.

A distinct effort has been made to render this report readable and comprehensible to the general reader, even to the provision of a glossary of the special terms used. Like most Stationery Office publications, it provides excellent value for money, and it is to be hoped that it will be widely read.

J. H. BURG;OYNE

\title{
ANIMAL LIFE ON WAVE-BEATEN ROCKS
}

\author{
BY DR. H. GORVETT \\ Department of Zoology and Applied Entomology, Imperial College of Science and Technology, \\ London, S.W.7
}

\begin{abstract}
$\mathrm{W}$ AVE-BEATEN rocks on exposed shores appear, at first sight, to be somewhat barren and devoid of life, but recent investigations have shown that here, as in other parts of the sea-shore, there exists a surprisingly large number and variety of animals.

The richness of the microfaunas of intertidal seaweeds and lichens has been amply demonstrated ${ }^{1}$; animal life in rock crevices is known to be both diverse and abundant ${ }^{2}$; and sorting and counting the inhabitants of even a very small rock pool may well keep a dozen students on a marine biology course busy for days. But most of the work done so far on this type of sea-shore ecology has been concerned with relatively sheltered habitats, and it is interesting to discover that the surface of a wave-beaten reef, where conditions would seem to be far less hospitable, may support a microfauna almost equally rich.
\end{abstract}

The site of the present investigation is a low rocky reef extending seawards from the western shore of the island of Oronsay in Argyllshire. Oronsay is about ten miles west of the island of Jura, and its western coast is exposed to the full force of Atlantic gales. The reef is a smooth hump of rock about 80 yards long and 12 yards wide, rising gently to a flattened crest about $6 \mathrm{ft}$. above mean low-water springs. Although the conditions here are not as rigorous as in certain other localities in the Western Isles, the degree of exposure is such that few of the larger seaweeds can survive on its surface, and these only as isolated tufts separated by wide expanses of weed-free rock. In place of the luxuriant cover of weed found above low-tide level in more sheltered situations, there are only stunted specimens of the exposed shore form of Fucus vesiculosus (F. vesiculosus L., f. linearis (Huds.), commonly known as f. evesiculosus ${ }^{3}$, small compact cushions of the red calcareous weed Corallina officinalis, a few individual plants of the thong-weed Himanthalia elongata, and occasional small tufts of Gigartina stellata. Below low-tide level the rocks are coated with the red calcareous Lithothamnion, partly hidden by a rela. tively prolific fringe of fucoids, in which the species of Laminaria ( $L$. digitata and $L$. hyperborea) are intermingled with a high proportion of Alaria esculenta. The latter is a weed that grows only in relatively exposed situations, and it is the only fucoid capable of withstanding conditions of extreme exposure such as are to be found on the isolated islet of Rockall4.

The only conspicuous animals on the areas of rock surface between the weed tufts are limpets, patches of barnacles, the anemone Actinia (fairly common in pools and crevices), and occasional little clusters of small mussels (also in crevices). The greater part of the animal population, however, has to be searched for more carefully, since it consists of small forms living in the shelter provided by the larger organisms, more especially by the encrusting barnacles and by the cushion-like growths of Corallina.

If the barnacles are scraped off the rock and separated from one another under a binocular microscope, and if their skeletal plates are taken apart, a host of small animals is revealed, some living in the empty shells of dead barnacles, others in the chinks and crevices between the plates of living ones. So numerous are these that a scraping from even a small area of rock surface cannot be fully sorted in less than two or three days. The record is held at present by a patch of barnacles from the flat top of the reef about $6 \mathrm{ft}$. above mean low-water springs. This measured $5 \mathrm{~cm} . \times 5 \mathrm{~cm}$. $(2$ in. $\times 2$ in.) and was found to contain a total of no less than 1,756 animals. These were all visible to the naked eye, and were picked out individually 